\title{
Analysis of Sleep Questionnaires of Commercial Vehicle Operators in Korea
}

\author{
Yoonjae Song ${ }^{1}$, Han Gyeol Park ${ }^{1}$, Seulki Song ${ }^{1}$, Dong-Han Lee ${ }^{1}$, Gene Huh${ }^{1}$, Se Jin Hyun ${ }^{1}$, \\ Goun Choe, , Sun A Han ${ }^{1}$, Jeong-Yeon Ji ${ }^{1}$, Jin Kook Kim ${ }^{2}$, and Hyun Jik Kim ${ }^{1}$ \\ ${ }^{I}$ Department of Otorhinolaryngology-Head and Neck Surgery, Seoul National University Hospital, \\ Seoul National University College of Medicine, Seoul; and ${ }^{2}$ Department of Otorhinolaryngology-Head and Neck Surgery, \\ Konkuk University School of Medicine, Seoul, Korea
}

\section{한국인 직업운전자에서 수면설문조사 결과 분석}

송윤재 ${ }^{1} \cdot$ 박한결 ${ }^{1} \cdot$ 송슬기 ${ }^{1} \cdot$ 이동한 ${ }^{1} \cdot$ 허 진 $^{1} \cdot$ 현세진 $^{1} \cdot$ 최고운 $^{1} \cdot$ 한선아 $^{1} \cdot$ 지정연 $^{1} \cdot$ 김진국 $^{2} \cdot$ 김현직 $^{1}$

서울대학교 의과대학 이비인후-두경부외과학교실, ${ }^{1}$ 건국대학교 의학전문대학원 이비인후-두경부외과학교실 ${ }^{2}$

Received October 21, 2018

Revised October 25,2018

Accepted October 25, 2018

Address for correspondence

Hyun Jik Kim, MD, PhD

Department of Otorhinolaryngology-

Head and Neck Surgery,

Seoul National University Hospital,

Seoul National University

College of Medicine, 103 Daehak-ro,

Jongno-gu, Seoul 03080, Korea

Tel $+82-2-2072-2203$

Fax $+82-2-745-2387$

E-mail hyunjerry@snu.ac.kr
Background and Objectives Obstructive sleep apnea (OSA) is highly prevalent in commercial vehicle operators (CMVOs). This study aimed to evaluate the poor sleep quality, daytime sleepiness, and the prevalence of self-reported OSA in CMVOs.

Subjects and Method We performed a retrospective review of the medical records of patients who visited a single institution with sleep problems from 2011 January to 2016 December. Among the patients, a total of 38 CMVOs was analyzed. Clinical information, questionnaires about sleep quality (Pittsburg sleep questionnaire, PSQI), excessive daytime sleepiness (Epworth sleepiness scale, ESS) and risk factors for OSA (STOP-Bang) were analyzed. The frequency of motor vehicle accidents and near accidents was assessed, and polysomnography (PSG) was used for OSA diagnosis purposes.

Results The mean age of the study population was $45.3 \pm 11.8$ years. The average score of PSQI, ESS, and STOP-Bang were $6.75 \pm 4.22,10.79 \pm 7.12$, and $4.62 \pm 3.34$, respectively. A significant association between near accidents and high-risk group of OSA was observed [odds ratio $(\mathrm{OR})=2.73,95 \%$ confidence interval $(\mathrm{CI})=1.08-4.48]$. Subjects with poor sleep quality showed significantly increased risk of near accidents $(\mathrm{OR}=2.34,95 \% \mathrm{CI}=1.01-3.56)$. Receiver operating characteristic curves of STOP-Bang questionnaire using apnea-hypopnea index (cut-off value $=5$ ) indicates that suspected OSA group predicted by STOP-Bang score was significantly correlated with OSA severity (area under curve $=0.72$, sensitivity $77.1 \%$, specificity $59.4 \%$ ).

Conclusion Administration of STOP-Bang questionnaire before a PSG can identify high-risk subjects, supporting its further use in OSA screening of CMVOs.

Korean J Otorhinolaryngol-Head Neck Surg 2019;62(4):221-7

Key Words Motor vehicles · Obstructive sleep apnea · Polysomnography ·

Surveys and questionnaires.

\begin{abstract}
서 론
폐쇄성 수면무호흡증(obstructive sleep apnea, OSA)은 수 면호흡장애의 한 종류로 주간 또는 수면 동안 증상이 있을

때 무호흡-저호흡지수(apnea-hypopnea index, AHI)나 호 흡장애지수(respiratory disturbance index)가 시간당 5 회 이 상인 경우, 또는 증상이 없을 때 시간당 15 회 이상인 경우로 정의되며, 다른 수면 질환이 없어야 한다.,2)
\end{abstract}

This is an Open Access article distributed under the terms of the Creative Commons Attribution Non-Commercial License (https://creativecommons.org/licenses/by-nc/4.0) which permits unrestricted non-commercial use, distribution, and reproduction in any medium, provided the original work is properly cited. 
폐쇄성 수면무호흡증으로 상기도의 폐쇄가 부분적 또는 완 전하게 발생하면 호흡이 감소되어 신체 내 저산소증과 과탄 산증이 유발되고, 교감신경이 항진되며, 수면 분절이 특징적 으로 나타난다. 이로 인해 폐쇄성 수면무호흡증이 진단되지 않거나 치료되지 않을 경우 고혈압, 뇌졸중, 당뇨병, 대사증후 군과 같은 내분비 질환 및 우울증 등의 신경정신과적인 질환 의 악화를 야기할 수 있다. 이외에도 집중력, 실행능력 및 인지 기능의 영구적 장애와 강한 상관관계가 있다고 알려져 있다.)

미국의 경우 30세 이상에서 전 인구의 2 4\%에서 폐쇄성 수 면무호흡증이 진단된다. ${ }^{4)}$ 우리나라는 3.2 4.5\%가량 유병률 을 보이며, 특히 남성, 높은 연령, 비만일수록 높다고 알려져 있다.5) 이외에도 특정 근무 환경과 같은 직업적 요소가 수면 장애에 영향을 미친다고 받아들여지고 있다.

그중에서도 특별히 직업운전자(commercial vehicle operators)의 경우 폐쇄성 수면무호흡증의 고위험군으로 여겨지고 있다.,7) 이와 관련된 한 대규모 연구는 19371 명의 직업운전 자를 대상으로 수면무호흡증을 선별하기 위한 온라인 설문조 사와 수면다원검사(polysomnography)를 시행하였고, 그중에 서 수면무호흡증의 고위험군으로 분류된 5908명(30.9\%) 중 $68 \%$ 에서 $\mathrm{AHI}$ 가 시간당 10 회 이상이었으며, 전체 직업운전자 의 경우 $21 \%$ 에서 $\mathrm{AHI}$ 가 시간당 10 회 이상이었다. ${ }^{8)}$ 또 다른 연구에 따르면 수면무호흡증인 직업운전사는 2 2 배의 교통 사고 위험도 및 3 5배의 인명피해 가능성을 가진다고 보고된 바 있다. ${ }^{7.9)}$

이런 관점에서 유럽연합(EU)은 직업운전자를 위한 운전 적 합성을 규제하는 지침을 정하여, 모든 운전자에게서 폐쇄성 수면무호흡증 위험에 대한 검사를 받아야 하고, 폐쇄성 수면 무호흡증 진단을 받은 운전자는 정기적인 치료 및 추적을 받 도록 하였다. 그럼에도 불구하고, 미국의 경우 수면무호흡증 증의 진단으로 인한 고용 문제가 관련되어 있어, 직업운전자 들의 검사에 대한 저항이 크다고 알려져 있다. ${ }^{10)}$

이처럼 직업운전자의 폐쇄성 수면무호흡증으로 인해 발생 하는 사회경제적인 비용에 주목하여 다양한 연구가 진행 중인 상황에서, 현재까지 이와 관련된 국내 연구는 미미한 실정이 다. 이에 본 연구는 폐쇄성 수면무호흡증이 의심되어 병원에 방문한 직업운전자에 대한 다양한 임상 변수 및 설문에 대 한 통계적 분석을 통하여 수면이 직업운전자의 사고 위험에 미치는 영향을 분석하고자 한다.

\section{대상 및 방법}

\section{대 상}

2011년 1월부터 2016년 12월까지 본원에 코골이, 수면무호
흡 및 과다한 주간졸림증을 주소로 방문한 환자 18세 이상 5135 명의 환자의 직업을 조사하였다. 그 중 직업운전사인 41 명(0.80\%)에 대하여 연구에 대한 동의를 구하였고, 이 중에 서 연구에 참여하고 싶지 않은 사람은 제외하였다. 이외 알려 진 다른 수면장애(기면증, 과다수면, 주기성 사지 운동장애 등)가 있거나 의심되는 환자, 신경과 및 정신과적 질환이 있 는 환자들은 연구 대상에서 제외하였다. 최종적으로 38 명에 대해서 설문조사를 포함한 연구를 시행하였다.

\section{방 법}

\section{대상자 설문 및 근무 형태 조사}

설문지에는 연령, 키, 몸무게, 결혼 유무, 교육수준(초등학 교, 중/고등학교, 대학교 이상), 당뇨 및 고혈압 등 기저 질환, 담배 및 음주 여부가 포함되었다. 체질량지수(body mass index)는 정상 $\left(25 \mathrm{~kg} / \mathrm{m}^{2}\right.$ 미만), 과체중 $\left(25 \mathrm{~kg} / \mathrm{m}^{2}\right.$ 이상 30 $\mathrm{kg} / \mathrm{m}^{2}$ 미만) 및 비만(30 kg/m 이상)으로 분류하였다. 교육 수준은 초등학교, 중/고등학교, 대학교 이상으로 구분하였 다. 신체활동 수준(시간/주)은 어떤 활동도 하지 않는 경우를 저활동군, 주당 4 시간 이상 운동하는 경우를 고활동군으로 정의하였다. 직업 만족도는 매우 만족에서 매우 불만족까지 5점 척도로 평가하였다. 아울러 1년간 인명 또는 재산상 손 실을 가져온 교통사고(motor vehicle accident)의 유무를 조 사하였고, 실제 사고는 나지 않았으나 사고상황을 피하기 위한 급한 조작을 해야 하는 상황인 아차사고(near accident)의 유무도 포함하였다. 본 연구는 서울대학교병원의 임상연구심 의위원회의 승인(IRB No. 1812-063-993)을 받아 진행되었 다. 연구 대상자로부터 서면동의서를 받았으며, 헬싱키 선언 (Declaration of Helsinki)을 준수했다.

\section{수면설문조사}

수면의 질은 임상 연구에 광범위하게 사용되는 피츠버그 수면 척도(Pittsburgh Sleep Quality Index, PSQI)에 의해서 평가되었다. 주관적인 수면 질, 수면 대기시간, 수면지속시간 수면장애, 수면제 사용 여부를 통해 수면 질에 대한 점수를 산정하였다. ${ }^{11)} \mathrm{PSQI}$ 점수가 6점 이상이 되는 경우 수면의 질 이 낮은 것으로 정의하였다. 또한 과도한 주간 졸음은 엡워 스 졸음증 척도(Epworth Sleepiness Scale, ESS)를 통해서 측정하였다. 10 이하의 값은 정상으로 판단하였고, 11점 이상 의 경우 증상이 있는 과다졸음으로 평가하였다. 폐쇄성 수면 무호흡증의 위험을 고려하기 위해 연구 대상자에 대해서 STOP-Bang 설문지를 조사하였다. 5점 이상일 경우 폐쇄성 수면무호흡증의 고위험군으로, 4점 또는 3점인 경우 중위험 
군, 2점 이하일 경우 저위험군으로 정의하였다.

\section{수면다원검사}

38 명의 환자 중에서 22 명이 야간 수면다원검사를 시행 받았 다. 수면다원검사는 Grass model 78(Astro-Med, Inc., West Warwick, RI, USA)를 사용했으며, 표준화된 방법에 따라 연 구 대상자들에게 각종 전극들과 감지기를 부착하여 뇌파, 안 전도, 심전도, 하악근전도, 호흡음, 구강 및 비강의 공기 흐름, 흥곽 호흡운동, 복부 호흡운동 및 혈중 산소포화도를 야간 수면시간 동안 지속적으로 측정하였다. 측정된 값은 국제판 독기준에 따라 수면의학 전문가 두 사람이 분석용 소프트웨 어(Xomnia 2005)를 사용하여 판독하였다. 이를 통해 무호 흡-저호흡지수, 총수면시간, 총수면시간, 총각성시간, 수면효 율 등의 값을 산출하였다. 무호흡-저호흡지수가 시간당 5 회 미만인 경우 정상, 5 15 미만이면 경증, 15 이상이면 중등도중증 폐쇄성 수면무호흡증으로 정의하였다.

\section{통계 분석}

기술 통계는 연속변수의 평균 및 표준편차, 비연속변수의 빈도와 백분율로 나타내었다. 사고가 있었던 운전자 및 아차 사고가 있었던 운전자에 대해서 예측 변수와 반응 변수 간의 연관성을 로지스틱 회귀분석(logistic regression analysis)으 로 분석하였고, 연속변수에 대해서 $\operatorname{Exp}(\mathrm{B})$ 및 비연속변수에 대하여 odds ratio(OR)와 95\% confidence interval( $95 \% \mathrm{CI}$ ) 를 계산하였다. STOP-Bang 설문에 따라 분류한 위험군 간 의 수면다원검사 결과의 차이 분석은 Mann-Whitney U test 를 이용하였다. 통계학적 유의 수준은 $p<0.05$ 로 하였으며, 자 료 분석을 위해 모든 통계 분석은 SPSS version 23.0(IBM Corp., Armonk, NY, USA)을 사용하였다.

\section{결 과}

\section{연구 대상의 특성}

본원에 코골이, 수면무호흡 및 과다한 주간졸림증으로 내 원한 환자들은 총 5135 명이었고, 그중에서 41 명(0.80\%)이 운 수업에 종사하였으며, 이는 무직인 사람을 제외하고 직업을 가진 사람들(4344명) 중 0.94\%에 해당하였다(Fig. 1).

PSQI, ESS, STOP-Bang 설문을 시행한 피험자 38명 중 37 명은 남성이었고, 평균 나이는 $45.3 \pm 11.8$ 세였다. 평균 체질량 지수는 $24.8 \pm 5.41 \mathrm{~kg} / \mathrm{m}^{2}$ 이었으며, 최소값과 최대값은 각각 19.4 와 $29.1 \mathrm{~kg} / \mathrm{m}^{2}$ 이었다. 커피 섭취는 하루 $3.13 \pm 2.72$ 잔이 었고, 응답자의 $10.5 \%$ 는 하루 10잔 이상의 커피를 마셨다. 흡 연자는 $76.3 \%$ 였으며, 음주를 $78.9 \%$ 가 한다고 보고하였으나

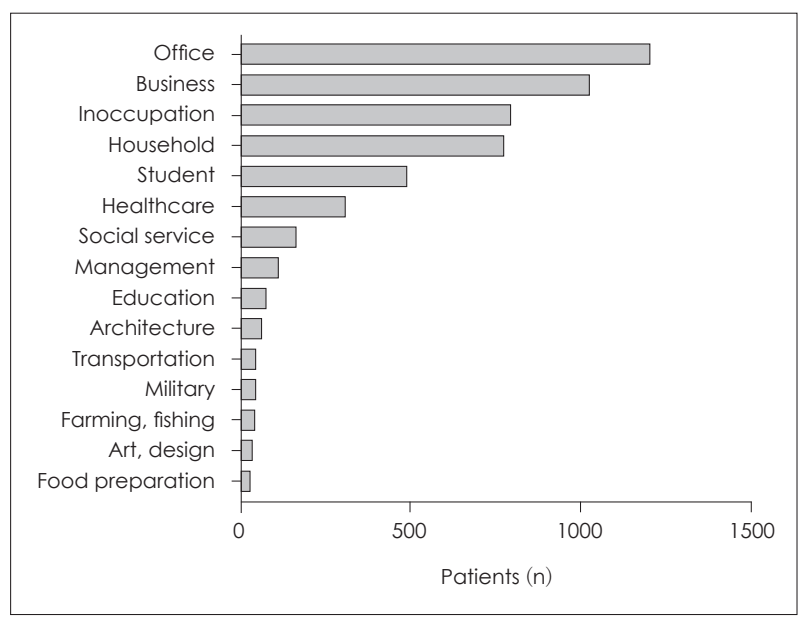

Fig. 1. Distribution of the patients' occupation.

운전할 때 마신다고 보고한 사람은 없었다. 운전자의 $36.8 \%$ 가 고혈압을, $23.7 \%$ 는 당뇨를 가지고 있었다.

여가시간 동안 운동을 전혀 하지 않는 저활동군는 전체 응 답자의 $63.2 \%$ 였고, 4시간 이상 운동을 하는 고활동군은 5.3\% 였다. $76.3 \%$ 의 운전자는 주당 50 시간 이상 운전한다고 하였 다. 직업 만족도는 $44.7 \%$ 가 만족한다고 응답했고, $15.8 \%$ 는 만족하지 못했다. 1년간 인명 또는 재산상 손실을 가져온 사 고가 1번이라도 있었던 경우는 14명이었다(Table 1).

\section{수면 설문의 분석}

평균 PSQI 점수는 $6.75 \pm 4.22$ 이었고, 최소 1점에서 최대 18 점까지 분포하였으며 $65.8 \%$ 의 운전자가 6점 이상의 낮은 수면 의 질을 가지고 있었다. 평균 $\mathrm{ESS}$ 점수는 $10.79 \pm 7.12$ 이었고, $36.8 \%$ 는 11점 이상의 과도한 주간 졸음을 호소하였다. STOPBang 설문에 따르면 수면무호흡증의 고위험군은 $34.2 \%$ 였 고, 저위험군은 23.7\%였다(Table 2).

\section{수면무호흡 위험군의 분석}

1 년간 사고 발생 여부와 임상변수 및 설문 결과에 대한 분 석을 시행한 결과, 나이, 비만도, 커피나 담배, 결혼 유무, 교육 정도, 여가시간의 운동, 운전하는 시간 및 강도는 위험도와 유 의미한 관계를 보이지 않았다. 하지만 수면의 질이 낮을수록 사고 발생 위험은 높은 경향을 보였다( $\mathrm{OR}=1.89, p=0.549)$.

아차사고의 경우 사고의 경우와 마찬가지로 다른 변수는 동 일한 경향을 보였으나, 수면의 질이 낮으면 사고 위험은 2.34 배 높아지고, $\mathrm{OSA}$ 의 고위험군인 경우 아차사고 위험도가 2.73 배 높았다(Table 3).

\section{수면다원검사 결과와 STOP-Bang 설문 타당도 평가}

STOP-Bang 설문으로 선별한 고위험군 중에서 수면다원검 
사를 시행한 환자는 12 명, 중위험 또는 저위험군 중에서 수 면다원검사를 시행한 환자들은 10 명이었다(Table 4). 고위험 군의 $\mathrm{AHI}$ 는 17.61(6.48 23.1)이었고, 이는 중/저위험군의 값인 9.01(2.55 12.3)과 유의한 차이가 있었다 $(p=0.032)$. AHI가 5 이상일 때 STOP-Bang 설문의 민감도 $77.1 \%$, 특이도 $59.4 \%$ 였 으며, receiver operating characteristic 커브를 통해 구한 area

Table 1. Clinical characteristics of the study population

\begin{tabular}{|c|c|c|}
\hline & $\mathrm{n}=38(\%)$ & Mean (SD) \\
\hline Male & $37(97.4)$ & \\
\hline Age (years) & & $45.3(11.8)$ \\
\hline$<40$ & $15(39.5)$ & \\
\hline$\geq 40$ & $23(60.5)$ & \\
\hline $\mathrm{BMI}\left(\mathrm{kg} / \mathrm{m}^{2}\right)$ & & $24.8(5.41)$ \\
\hline Coffee intake (units/working day) & & $3.13(2.72)$ \\
\hline Current smoking & $29(76.3)$ & \\
\hline Alcohol drinking & $30(78.9)$ & \\
\hline HTN & $14(36.8)$ & \\
\hline DM & $9(23.7)$ & \\
\hline \multicolumn{3}{|l|}{ Marital status } \\
\hline Single or divorced & $7(18.4)$ & \\
\hline Married & $31(81.6)$ & \\
\hline \multicolumn{3}{|l|}{ Education } \\
\hline Primary & $1(2.6)$ & \\
\hline Lower secondary & $5(13.2)$ & \\
\hline Upper secondary & $28(73.7)$ & \\
\hline Tertiary & $4(10.5)$ & \\
\hline \multicolumn{3}{|l|}{ Leisure time physical activity (h/wk) } \\
\hline 0 & $24(63.2)$ & \\
\hline $2-4$ & $12(31.6)$ & \\
\hline 4 & $2(5.3)$ & \\
\hline \multicolumn{3}{|l|}{ Driving experience (years) } \\
\hline$<15$ & $26(68.4)$ & \\
\hline$\geq 15$ & $12(31.6)$ & \\
\hline \multicolumn{3}{|l|}{ Driving time (h/wk) } \\
\hline$<50$ & $29(76.3)$ & \\
\hline$\geq 50$ & $9(23.7)$ & \\
\hline \multicolumn{3}{|l|}{ Work intensity } \\
\hline Mild & $5(13.2)$ & \\
\hline Moderate & $16(42.1)$ & \\
\hline Severe & $17(44.7)$ & \\
\hline \multicolumn{3}{|l|}{ Job satisfaction } \\
\hline Dissatisfied & $6(15.8)$ & \\
\hline Neutral & $15(39.5)$ & \\
\hline Satisfied & $17(44.7)$ & \\
\hline \multicolumn{3}{|l|}{ MVA } \\
\hline Accident & $14(36.8)$ & \\
\hline Near accident & $21(55.3)$ & \\
\hline
\end{tabular}

SD: standard deviation, BMI: body mass index, HTN: hypertension, DM: diabetes mellitus, MVA: motor vehicle accident under curve(AUC)는 0.72였다(Fig. 2).

\section{고 찰}

본 연구는 병원에 방문한 환자 중에서 직업운전사를 대상 으로 시행한 연구이다. 한국고용정보원에서 발간한 2016년 한국직업정보 보고서에 따르면 전체 직종 중에서 운수업은 $4.0 \%$ 에 해당하였다. 이번 연구에서 직업운전자는 $0.94 \%$ 에 해

Table 2. Sleep data of the study population

\begin{tabular}{lcc}
\hline & $\mathrm{n}=38(\%)$ & Mean (SD) \\
\hline PSQI score & & $6.75(4.22)$ \\
Subjective sleep quality & & $1.21(0.82)$ \\
Sleep latency & & $0.97(0.87)$ \\
Sleep duration & $0.94(0.79)$ \\
Sleep efficiency & $0.65(0.55)$ \\
Sleep disturbance & $1.37(1.14)$ \\
Use of sleep medication & & $0.49(0.52)$ \\
Daytime dysfunction & & $1.12(1.01)$ \\
PSQI score $>5$ & $25(65.8)$ & \\
ESS score & & $10.79(7.12)$ \\
ESS score > 10 & $14(36.8)$ & \\
STOP-Bang score & & \\
High risk of OSA & $20(52.6)$ & \\
Moderate risk of OSA & $15(39.5)$ & \\
Low risk of OSA & $3(7.9)$ & \\
\hline
\end{tabular}

SD: standard deviation, PSQI: Pittsburgh Sleep Quality Index, ESS: Epworth Sleepiness Scale, OSA: obstructive sleep apnea

Table 3. Association of sleep disorders and demographic variables with accidents

\begin{tabular}{lcc}
\hline & $\begin{array}{c}\text { Accident OR } \\
(95 \% \mathrm{Cl})\end{array}$ & $\begin{array}{c}\text { Near accident OR } \\
(95 \% \mathrm{Cl})\end{array}$ \\
\hline Age & $1.01(0.78-1.14)$ & $1.06(0.79-1.33)$ \\
BMI & $1.15(0.71-1.35)$ & $1.09(0.69-1.24)$ \\
Coffee & $0.91(0.68-1.42)$ & $0.88(0.48-1.36)$ \\
Current smoking & $0.76(0.32-1.08)$ & $0.62(0.25-1.14)$ \\
Underlying disease & $1.13(0.88-1.51)$ & $1.04(0.79-1.42)$ \\
Marital status & $1.05(0.67-1.26)$ & $1.09(0.68-1.37)$ \\
Educational level & $0.97(0.59-1.83)$ & $1.03(0.62-1.72)$ \\
Physical activity & $0.98(0.89-1.42)$ & $0.84(0.45-1.51)$ \\
Driving experience & $1.05(0.76-1.13)$ & $1.12(0.91-1.62)$ \\
Driving time & $1.12(0.88-1.42)$ & $1.07(0.89-1.43)$ \\
Work intensity & $1.28(0.94-1.98)$ & $1.12(0.85-2.12)$ \\
Job satisfaction & $0.82(0.83-1.02)$ & $0.79(0.74-1.06)$ \\
PSQl score $>5$ & $1.89(0.95-2.42)$ & $2.34(1.01-3.56)^{*}$ \\
ESS score $>10$ & $1.67(0.88-1.96)$ & $1.52(0.92-1.78)$ \\
High risk of OSA & $1.54(0.89-1.48)$ & $2.73(1.08-4.48)^{*}$ \\
\hline
\end{tabular}

$* p<0.05$. BMI: body mass index, PSQI: Pittsburgh Sleep Quality Index, ESS: Epworth Sleepiness Scale, OSA: obstructive sleep apnea, OR: odds ratio, Cl: confidence interval 
Table 4. Demographics and polysomnographic data according to risk groups classified with STOP-Bang questionnaire

\begin{tabular}{lccc}
\hline & High risk $(\mathrm{n}=12)$ & Low/moderate risk $(\mathrm{n}=10)$ & $\mathrm{p}$ \\
\hline Age (years) & $49.7(10.6)$ & $44.3(11.1)$ & 0.784 \\
BMI $\left(\mathrm{kg} / \mathrm{m}^{2}\right)$ & $26.1(22.2-29.3)$ & $23.7(20.9-28.8)$ & 0.241 \\
PSQI score & $7(4.3-14.3)$ & $5(3-8.3)$ & 0.074 \\
ESS score & $13(10.3-15)$ & $10(7-13.3)$ & 0.067 \\
AHI & $17.61(6.48-23.1)$ & $9.01(2.55-12.3)$ & $0.032^{*}$ \\
Lowest O2 (\%) & $86.2(81.8-92.4)$ & $89.4(82.8-95.2)$ & 0.495 \\
Snoring (\%) & $5.47(2.3-13.10)$ & $3.74(1.12-9.71)$ & 0.191 \\
\hline
\end{tabular}

All values except age are reported as median (interquartile range). $* p<0.05$. BMI: body mass index, PSQI: Pittsburgh Sleep Quality Index, ESS: Epworth Sleepiness Scale, AHI: apnea-hypopnea index

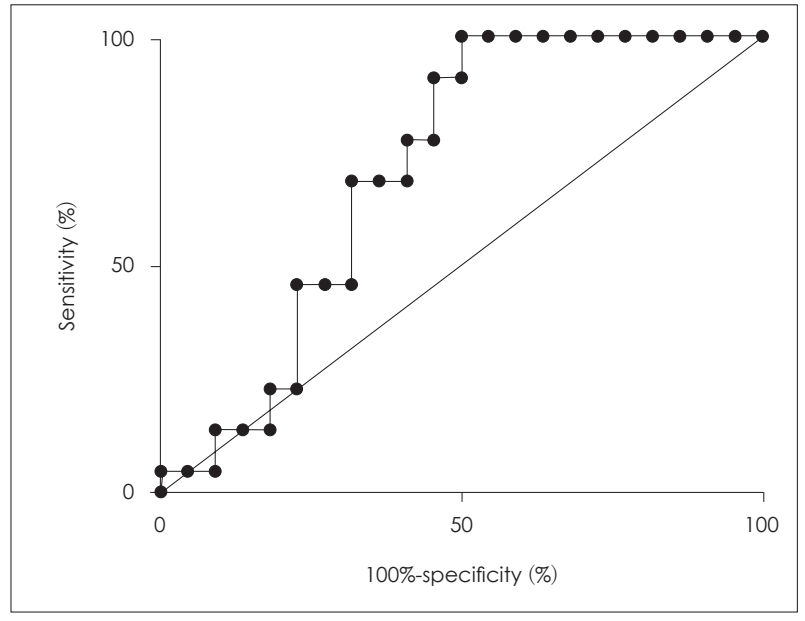

Fig. 2. Receiver operating characteristic curve of STOP-Bang questionnaire using apnea-hypopnea index $\geq 5$ cutoff value.

당하였는데, 이는 직업운전자의 경우 수면질환으로 인해 실제 로 방문하는 비율이 타 직종에 비해서 더 적다고도 해석할 수 있다.

PSQI를 이용하여 직업운전자에 대한 수면의 질을 평가하 는 연구에서는 유병률이 다양하게 보고되었다. 이스라엘에서 160 명의 직업운전자를 대상으로 조사한 결과에 의하면 $21.3 \%$ 가 수면이 질이 낮았다. ${ }^{12)}$ 하지만 브라질에서 보고된 두 논문 에서는 좀 더 높은 유병률을 확인할 수 있었다. 260명의 직업 운전사를 대상으로 한 연구에서는 $35.4 \%$ 가 수면의 질이 낮 다고 보고되었고, ${ }^{13)} 300$ 명을 대상으로 한 다른 연구에서는 낮은 수면의 질을 가진 직업운전사가 $46.3 \%$ 이었다. ${ }^{14)}$ 이번 연 구에서는 직업운전사의 과반이 넘는 $65.8 \%$ 가 낮은 수면의 질을 가지고 있었다. 이는 기존에 알려진 유병률보다 높은 수 치로 수면의 질이 낮은 사람들이 병원 이용에 적극적이라고 볼 수 있다. 하지만 같은 조건에서 직업운전사들을 대상으로 유병률을 조사하기 전에는 명확한 결론을 내리긴 어렵다.

$\mathrm{ESS}$ 를 통해 본 연구에서는 설문 점수 11점 이상의 과도한 주간졸림증을 호소하는 직업운전사는 $36.8 \%$ 이었다. 476 명을 대상으로 한 벨기에 직업운전자의 경우 $18 \%$ 가 주간졸림증
을 호소하였다. ${ }^{15)}$ 반면 호주에서 직업운전자 2342명을 대상 으로 대규모 연구에서는 $24.1 \%$ 에서 과도한 주간졸림증이 있 다고 보고하였다. ${ }^{16)}$ 브라질 직업운전자에서는 각각 21.7 46\% 의 주간졸림증이 관찰되었다. ${ }^{13,14)}$ 이번 연구에서는 알려진 비 슷한 정도의 주간졸림증이 있었으나 병원에 찾아온 직업운 전사에 국한되었으므로 분석에 한계가 있다.

수면무호흡증은 성인 인구의 2 4\%로 알려져 있고, 직업운 전자의 경우 15 56\%로 더 높게 보고되었다. ${ }^{17,18)}$ 수면무호흡 증에 대한 선별 검사로 사용되는 설문은 베를린 설문지(Berlin questionnaire), Four-Variable screening tool, STOP-Bang 등이 있으며, STOP-Bang 설문의 경우 8개의 항목으로 비교 적 간략하게 구성되어 있어 선별검사에 용이하다. 본 연구에 서 STOP-Bang 설문을 통한 수면무호흡 증후군의 고위험군 은 $52.6 \%$ 으로 관찰되었다. 이전 연구에서 STOP-Bang 설문 을 이용한 직업운전자에 설문 통해 $27.9 \%$ 의 유병률이 보고된 바 있다. ${ }^{19)}$ 이번 연구에서 월등히 높은 수면무호흡증의 고위 험군의 비율은 직업운전자를 대상으로 한 연구와 병원을 대 상으로 한 연구의 차이로 해석할 수 있다.

총 38명에 해당하는 연구 대상 중에서 남성은 37명이었고, 1 명만 여성이므로, 성별에 따른 분석이 의미가 없었다. 우리 나라 직업운전자의 경우 남성 비율은 $95.6 \%$ 로 알려져 있고, 이번 연구 대상의 경우 $97.3 \%$ 가 남성으로 비슷한 성비를 확 인하였다. 성비에 따른 차이를 확인하기 위해서는 좀 더 큰 표 본에 대해서 연구를 시행해야 할 것으로 생각된다.

이번 연구에서 직업운전자들은 $78.9 \%$ 가 음주를 한다고 하 였으나 운전 당일 음주한다고 응답한 사람은 없었고, 따라서 당일 음주와 사고 또는 아차사고와의 연관성은 관찰되지 않 았다. 음주의 경우 자기 보고 설문에 근거하였으므로, 도로교 통법과 관련하여 섭취에 대해 과소평가되었을 가능성이 있 다. 향후 좀 더 면밀한 연구를 위하여 혈중알코올농도와 사고 또는 아차사고와의 관계에 대해서 연구해 볼 필요가 있다.

이번 분석 결과에서 흡연, 커피, 결혼 유무, 교육 정도, 여가 활동도, 업무강도 및 직업만족은 사고와 아차사고의 위험과 
유의미한 관련이 없었다.

여러 나라에서 이미 시도하고 있듯이 우리나라에서도 스크 리닝 테스트를 통해 사고의 위험도가 높은 직업운전자를 조 기에 발견하는 것이 필요하다. 국가적인 차원에서의 노력뿐 아니라 체계적인 스크리닝을 통해 수면장애 위험에 처한 개 인을 조기에 발견하려는 노력은 이미 소규모 기업에서 실용 적인 방안으로 시도되었다고 보고된 바 있다. ${ }^{20)}$ 본 연구에서 시행한 설문조사로 사고의 위험을 증가하는 변수를 찾지는 못했지만, 아차사고는 낮은 수면의 질 $(\mathrm{OR}=2.34,95 \% \mathrm{CI}=$ 1.01 3.56)과 $\mathrm{OSA}$ 고위험군일 때( $\mathrm{OR}=2.73,95 \% \mathrm{CI}=1.08$ 4.48) 더 많이 난다는 결과를 얻었다. 결과를 얻기 위한 설문으로 $\mathrm{PSQI}$ 는 19 개의 문항으로 되어 있기 때문에, 좀 더 편의성이 높은 STOP-Bang을 통해 아차사고의 위험군을 선별하는 것 이 도움이 될 것이다.

선별 설문지에 대한 타당도를 분석한 기존의 연구가 있지 만, 직업운전자를 대상으로 폐쇄성 수면무호흡증을 선별하 는 타당도 분석 연구는 드물다.

선별 도구로서의 설문지의 신뢰도는 설문지 종류, 수면클 리닉이나 지역사회와 같은 연구 대상 차이, 수면무호흡증의 중증도에 따라 다양하게 나타나기 때문에 분석에 주의를 요 한다. ${ }^{21-23)}$

수면클리닉에 방문했던 128명을 대상으로 한 연구에서 STOP-Bang 설문은 AHI 15 이상인 경우 민감도와 특이도 가 각각 $93 \%, 28 \%$ 였고, AHI 5 이상인 경우 민감도와 특이 도는 각각 $90 \%, 42 \%$ 였다. ${ }^{24)}$ 반면 100 명의 직업운전사를 대 상으로 한 연구에서 STOP-Bang 설문은 AHI 15 이상일 때 민감도와 특이도가 각각 $100 \%, 40 \%$ 였으며, AHI 5 이상일 때 민감도와 특이도는 각각 $86 \%, 54 \%$ 로 보고했다. ${ }^{25)}$ 병원을 방 문했던 직업운전사를 대상으로 22 명을 분석한 이번 연구에 서 AHI 5 이상일 때 민감도와 특이도는 각각 $77 \%, 59 \%$ 로 민 감도는 낮고, 특이도는 다소 높은 결과를 얻었으며, AUC는 0.72 로 선별검사로서 타당성을 검증하였다. 이에 본 연구의 결과로서 STOP-Bang 설문이 단독으로 사용되기는 어렵지 만, 고위험군을 선별하는 유용한 도구로써 사용될 수 있다.

이번 연구는 횡단 연구이므로 분석된 변수 간에는 인과 관 계에 대해서 알기는 힘들다. 또한 병원에 방문한 운전자를 대 상으로 한 연구로 선택 편견(selective bias)이 있을 수 있어 일 반화가 제한될 수 있다. 그리고, 직업운전자는 수면장애가 있 어서 사고가 많이 났거나 실제 사고의 빈도가 높은 운전자가 직업을 더이상 수행하지 못하거나 다른 직업을 찾을 수 있기 때문에, 본 연구에서 실제 사고의 유병률은 과소평가가 될 수가 있다. ${ }^{26)}$

더불어 설문조사 기반의 연구로서, 결과 값의 편견이 있을
수 있다는 한계가 있다. 특히 일상생활에서의 과도한 주간 졸음증에 대한 설문인 $\mathrm{ESS}$ 는 직업운전자의 경우 직업보전 을 위해 다른 설문에 비해 보수적으로 평가되었을 가능성이 있다. 마지막으로, 연구 대상이 적어 분석 결과가 통계적 의 미를 가지는 데 한계가 있어, 후속 연구에서는 보다 많은 직 업운전자를 대상으로 한 분석이 필요할 것으로 생각된다.

결론적으로, 직업운전자에서 낮은 수면의 질과 수면무호 흡의 고위험군에서 아차사고의 위험도는 높다. STOP-Bang 설문은 직업운전자에서 수면무호흡의 고위험군을 선별하는 데 유용하다.

\section{Acknowledgments}

This work was supported by a project for the Future Development Committee of Korean Rhinologic Society in 2018.

\section{ORCID}

Hyun Jik Kim https://orcid.org/0000-0001-8631-928X

\section{REFERENCES}

1) Sateia MJ. International classification of sleep disorders-third edition: highlights and modifications. Chest 2014;146(5):1387-94.

2) Epstein LJ, Kristo D, Strollo PJ Jr, Friedman N, Malhotra A, Patil SP, et al. Clinical guideline for the evaluation, management and longterm care of obstructive sleep apnea in adults. J Clin Sleep Med 2009; 5(3):263-76.

3) Gagnon K, Baril AA, Gagnon JF, Fortin M, Décary A, Lafond C, et al. Cognitive impairment in obstructive sleep apnea. Pathol Biol (Paris) 2014;62(5):233-40.

4) Young T, Palta M, Dempsey J, Skatrud J, Weber S, Badr S. The occurrence of sleep-disordered breathing among middle-aged adults. N Engl J Med 1993;328(17):1230-5.

5) Kim J, In K, Kim J, You S, Kang K, Shim J, et al. Prevalence of sleepdisordered breathing in middle-aged Korean men and women. Am J Respir Crit Care Med 2004;170(10):1108-13.

6) Karimi M, Eder DN, Eskandari D, Zou D, Hedner JA, Grote L. Impaired vigilance and increased accident rate in public transport operators is associated with sleep disorders. Accid Anal Prev 2013; 51:208-14.

7) Vennelle M, Engleman HM, Douglas NJ. Sleepiness and sleeprelated accidents in commercial bus drivers. Sleep Breath 2010;14(1): $39-42$.

8) Berger M, Varvarigou V, Rielly A, Czeisler CA, Malhotra A, Kales $\mathrm{SN}$. Employer-mandated sleep apnea screening and diagnosis in commercial drivers. J Occup Environ Med 2012;54(8):1017-25.

9) Tregear S, Reston J, Schoelles K, Phillips B. Obstructive sleep apnea and risk of motor vehicle crash: systematic review and meta-analysis. J Clin Sleep Med 2009;5(6):573-81.

10) Hiestand D, Phillips B. Obstructive sleep apnea syndrome: assessing and managing risk in the motor vehicle operator. Curr Opin Pulm Med 2011;17(6):412-8.

11) Buysse DJ, Reynolds CF 3rd, Monk TH, Berman SR, Kupfer DJ. The Pittsburgh Sleep Quality Index: a new instrument for psychiatric practice and research. Psychiatry Res 1989;28(2):193-213.

12) Sabbagh-Ehrlich S, Friedman L, Richter ED. Working conditions and fatigue in professional truck drivers at Israeli ports. Inj Prev 2005;11(2):110-4.

13) Souza JC, Paiva T, Reimão R. Sleep habits, sleepiness and accidents 
among truck drivers. Arq Neuropsiquiatr 2005;63(4):925-30

14) de Pinho RS, da Silva-Júnior FP, Bastos JP, Maia WS, de Mello MT, de Bruin VM, et al. Hypersomnolence and accidents in truck drivers: a cross-sectional study. Chronobiol Int 2006;23(5):963-71.

15) Braeckman L, Verpraet R, Van Risseghem M, Pevernagie D, De Bacquer D. Prevalence and correlates of poor sleep quality and daytime sleepiness in Belgian truck drivers. Chronobiol Int 2011;28(2):126-34.

16) Howard ME, Desai AV, Grunstein RR, Hukins C, Armstrong JG, Joffe D, et al. Sleepiness, sleep-disordered breathing, and accident risk factors in commercial vehicle drivers. Am J Respir Crit Care Med 2004;170(9):1014-21.

17) Shattell M, Apostolopoulos $Y$, Collins $C$, Sönmez S, Fehrenbacher C. Trucking organization and mental health disorders of truck drivers. Issues Ment Health Nurs 2012;33(7):436-44.

18) Smith B, Phillips BA. Truckers drive their own assessment for obstructive sleep apnea: a collaborative approach to online selfassessment for obstructive sleep apnea. J Clin Sleep Med 2011;7(3): 241-5.

19) Evans KA, Yap T, Turner B. Screening commercial vehicle drivers for obstructive sleep apnea: tools, barriers, and recommendations. Workplace Health Saf 2017;65(10):487-92.

20) Garbarino S, Magnavita N. Obstructive sleep apnea syndrome (OSAS), metabolic syndrome and mental health in small enterprise workers.
Feasibility of an Action for Health. PLoS One 2014;9(5):e97188.

21) Ahmadi N, Chung SA, Gibbs A, Shapiro CM. The Berlin questionnaire for sleep apnea in a sleep clinic population: relationship to polysomnographic measurement of respiratory disturbance. Sleep Breath 2008;12(1):39-45.

22) Sharma SK, Vasudev C, Sinha S, Banga A, Pandey RM, Handa KK. Validation of the modified Berlin questionnaire to identify patients at risk for the obstructive sleep apnoea syndrome. Indian J Med Res 2006;124(3):281-90.

23) Flemons WW, Whitelaw WA, Brant R, Remmers JE. Likelihood ratios for a sleep apnea clinical prediction rule. Am J Respir Crit Care Med 1994;150(5 Pt 1):1279-85.

24) Pereira EJ, Driver HS, Stewart SC, Fitzpatrick MF. Comparing a combination of validated questionnaires and level III portable monitor with polysomnography to diagnose and exclude sleep apnea. J Clin Sleep Med 2013;9(12):1259-66.

25) Popević MB, Milovanović A, Nagorni-Obradović L, Nešić D, Milovanović J, Milovanović APS. Screening commercial drivers for obstructive sleep apnea: validation of STOP-Bang questionnaire. Int J Occup Med Environ Health 2017;30(5):751-61.

26) Ribet C, Derriennic F. Age, working conditions, and sleep disorders: a longitudinal analysis in the French cohort E.S.T.E.V. Sleep 1999; 22(4):491-504. 